\title{
Setting National Minimum Wages for Nepal: A Need-Based Approach
}

\author{
Nirmal Kumar Raut $^{1}$
}

\begin{abstract}
Method of setting minimum wages has been a debatable issue across the world. Various countries have adopted various methods of minimum wage determination process primarily formulas, government rate setting, unionbargained rates, and rate recommended by an expert body. International Labour Organization (ILO) puts forth that the process of setting-up minimum wages should be scientific and accommodative of the needs of the workers and their families. Although minimum wages remains an utmost priority as a redistributive tool, studies show that its fixation are mostly driven by political interest of the incumbent government and the interest of the private sector. Nepal is not an exception to this. This paper attempts to propose a need based method of setting minimum wages for Nepal. In addition to the food and non-food information, unlike previous need based approaches, this study uses housing information from the nationally representative household survey to derive the minimum wages for Nepal. The minimum monthly salary/wages at 2019/20 prices per household is estimated at NRs. 21799 and daily wages is estimated at NRs. 838.43. This study is expected to guide policy makers in setting evidence-based minimum wages for Nepal.
\end{abstract}

Kew words: Minimum wage, Need-based, Nutrition, Food and non-food items

\section{Introduction}

Minimum wages were first introduced in the early 19th century. Currently, most of the countries around the world have set the minimum wage rate. However, minimum wages can be set in different ways and can have fundamentally different roles in different countries. They can be set by governments and through the collective bargaining process if the negotiated wages are declared binding for all firms in an industry. It may seem that minimum wage would reduce employment by turning off the potential workers from taking up the new jobs or incumbent workers working additional hours. In essence, minimum wage is a redistributive tool primarily used to empower disadvantaged group by redistributing earnings to low-paid workers (Addison \& Blackburn, 1999; Freeman, 1996; Stigler, 1946).

1 Dr. Raut is a lecturer at Central Department of Economics, Tribhuvan University, Nepal. Email: nirmal.raut@cdec.tu.edu.np 
It also stimulates aggregate demand (Herr \& Kazandziska, 2011) primarily of low-income households since their propensity to consume is high vis-à-vis high-wage earners; this further induces increase in output in the economy (Blinder, 2008). Thus, minimum wages set at the right level may help low-paid workers without harming employment prospects (Dickens, 2015). It is also expected that this may reduce out-migration by paying minimum wages comparable to the average wages paid in Gulf Countries and Malaysia.

The ILO Resolution - 2010 considers minimum wage as a tool for social protection and poverty reduction (ILO, 2014). The Minimum Wage Fixing Convention-1970 (No. 131) of the ILO emphasizes that the process of setting-up of minimum wage in a country should be the result of evidence-based social dialogue, taking into account both the needs of the workers and their families and economic factors. Recently the ILO Centenary Declaration-2019 for the Future of Work also reiterates its focus on adequate minimum wages, statutory or negotiated. Similarly, Convention No. 131 calls for setting minimum wages after careful consideration of both needs of workers and their families as well as economic factors. Furthermore, the ILO minimum wage policy guide also emphasizes the need for an evidence-based transparent methodology for the fixation of levels of minimum wages in a country (ILO, 2014; Dickens 2015).

Today, more than 90 percent of ILO member states have one or more minimum wages set either through legislation or binding collective agreements. Specifically, there is a substantial variation in minimum wages determination process across countries. The methods that are largely adopted include formulas, government rate setting, union-bargained rates, and rate recommended by an expert body (Dickens, 2015). Although it is widely agreed/observed that the expert bodies recommending evidence-based minimum wages are more likely to respond to the change in economic conditions and agreeable to businesses and workers without political interference, many governments including that of Nepal sets minimum wage rates usually on ad-hoc basis. This calls for the need to fix minimum wages that is both scientific and accommodative of the concerns of all parties.

Nepal started fixing minimum wages since 1965. The Factory and Factory Workers Act was enacted in 1959 as the first labour legislation with the provision of minimum wages covering the manufacturing sector only. The Labour Act -1992 has a provision of the fixation of minimum wage on the basis of recommendations made by the Minimum Wage Fixation Committee. The government can fix minimum wages of the workers only in case of the absence of the committee. The temporary/ad-hoc nature of the wage fixation committee and its non-expert members comprising of representatives of workers, managers and Government further dilutes the prospect of fixing minimum wages that is scientific ${ }^{2}$ and accommodative, as argued earlier.

Nepal lacks scientific method of fixing minimum wages that possess an ability to periodically adjust itself along with the underlying changes in its determining factors. Setting

2 On August 2018, during a Regional Training Course on "Designing and Implementing Effective wage Policies in New Delhi, mentioned that the mechanism for fixing minimum wage in Nepal should be scientific based on evidence (Estupinan, 2019). 
the level of minimum wages and adjusting the same on a regular basis is perhaps the most challenging part of minimum wage process in a country. Therefore, the primary objective of this paper is to produce fresh evidence for minimum wage for Nepal. As mentioned earlier, Nepal provisioned minimum wages in manufacturing sector in its first ever labour legislation Factory and Factory Worker's Act in 1959. However, it started fixing minimum wages only from 1965. The Labour Act-1992 specifically mentions the procedures to be followed to fix the minimum wages. It provisions that the Go vernment of Nepal may fix minimum wages on the recommendations of the Minimum Remuneration Fixation Committee comprising of representatives of workers, managers, and government. The Government of Nepal later amended the minimum wage under Labor Act-1992 by publishing a Gazette Notice in 2016 that prohibits an employer from entering into an agreement with its employee for paying salary/wage and benefits that are less than what is prescribed by the Government of Nepal.

As indicated earlier, the new Labour Law raises at least two important concerns. First, it remains silent about the institution of permanent Minimum Wage Fixation Committee that can recommend evidence-based minimum wages balancing both the needs of the workers and the economic effects it may have. Second, it does not ensure progressive compliance to protect all workers and enable the development of sustainable enterprises.

Global experience on fixation of minimum wages has been diverse. The mechanism for setting minimum wages may take various forms. Whatever the mechanism, different and credible methodologies should be used to ensure that deliberations and arguments are supported by evidence and conclusions are not driven by biases (ILO, 2014). In this context, it would be helpful if a scientific process of setting minimum wages is developed that can provide an evidence-based guidance to the policy makers. It is expected that this paper can contribute towards fulfilling the knowledge gap in this regard and thereby draw attention of the policy makers while revising the minimum wages in Nepal.

\section{Data and Methodology}

Methodologically, various approaches have been used to estimate the minimum wages in different countries. For example, Brazil uses formula based approach which not only preserves the purchasing power of workers but also makes workers participate in the economic success of the country. In any case, Brazil's Constitution asserts that the minimum wage should be adequate to cover the basic needs of housing, food, education, health, leisure, clothing, hygiene, transportation and social security and that it should be periodically adjusted to account for the change in purchasing power (ILO, 2014). Russian Federation also posits that the minimum wage should not be less than subsistence wages and that it should be revised depending upon the changing socio-economic conditions. Hence, the approach is essentially a need-based income approach that ensures minimum consumption requirements. The approach considers both food and non-food consumption requirements; in case of food consumption, it calculates calorie intake separately for an adult male, an adult female, a pensioner and children (ibid). In case of China, the minimum wages should be set higher than the social relief fund and unemployment benefits and lower than the average wage in the 
locality. In any case, however, while fixing minimum wages, it should largely use statistics on cost of living, the consumption price index, average wage of workers, labour productivity, the urban economic situation, and the level of economic development. Besides, the minimum wages should be adjusted at an average growth rate of 10 percent in order to account for the change in purchasing power. Hence, we observe that there are no specific models to consider while setting minimum wages; most countries considers indicators that reflects the need of the workers and families and the changing socio-economic condition (Ibid).

Countries such as India and Maldives uses need based approach in determining minimum wages. They take into account calorie, protein and fat requirements in food consumption as a pre-requisite to a balanced diet unlike previous instance of considering only calories; thus taking into account the changing nutritional requirements and nutritional intakes in India. The method also accounts for changing demographic structure by estimating per family consumption unit which considers the recommended nutritional requirement by age and gender. Besides food consumption, the approach also accounts for non-food consumption for essential and other nonfood items (MoLE/GoI, 2019). The method used in our study closely resembles to that of India. However, we add value to this knowledge by also considering cost of housing to estimate the minimum wages. The cost of housing is important to the workers residing primarily in urban areas since it accounts for significant proportion of their household expenditure.

Following Minimum Wage Policy Guide of ILO, this paper uses a nationally representative data and follows appropriate methodology to define and compute the minimum wage level of Nepal. A need-based approach is generally recommended while defining the needs of workers and their families for the minimum wage exercise. The need-based approach essentially considers minimum needs, in terms of the consumption expenditure of the worker and his or her family. The consumption needs are broadly categorized into food and non-food needs. While the need of food component is defined as the minimum level of food expenditure required for maintaining workers efficiency and the nutritional needs of their family, the nonfood component considers a minimum level of expenditure required to maintain a reasonable standard of living. In order to estimate the minimum wage that would be sufficient to cover the household expenses, this approach will also consider number of full-time equivalent workers in the family by exploiting the information about the average number of family wage earners.

In this paper, hence, a need-based approach is used to estimate minimum consumption needs of workers in the food and non-food categories and then the minimum wage is estimated using a method of minimum cost of purchasing a consumption basket in these categories. A third wave of Nepal Living Standard Survey (NLSS-III), a nationally representative household survey, is used to identify the food and non-food consumption of the households. Using the consumption information, nutritional contents of food items are identified and then the recommended nutritional norms are used to estimate minimum cost of food expenditure using fractile based distribution. For non-food expenditure, all the non-food items are classified into essential and other categories and then the non-food expenditure of median class and $\mathrm{n}^{\text {th }}$ fractile of consumption expenditure distribution are used for estimation of minimum wage. This study also adds value by adding to the minimum wage the estimated rent of housing separately. Finally, the total consumption expenditure need of workers and 
their families are adjusted with average number of wage workers per households and current unemployment rate to estimate minimum wages.

\section{Estimation of Minimum Needs}

The total consumption expenditure (TCE) needs of the household is calculated by summing up the food expenditure (FE) and the non-food expenditure (NFE) as shown in equation/identity (1).

$$
\mathrm{TCE}=\mathrm{FE}+\mathrm{NFE}
$$

Then, nutrition requirements and adult equivalent consumption unit is computed to derive the minimum food consumption needs of the household. For this purpose, average daily requirements of nutrients per adult person at national level are computed by utilizing a balanced diet approach'. In other words, minimum daily requirements of nutrients mainly the proteins, fats, and calories required for a balanced diet are considered. ${ }^{3}$ Thereafter, using the recommended nutritional allowance (RNA) for calories, fats and proteins for individuals in different age groups, gender and workload type, as available from Nepalese food composition table (DFTQC, 2017) and combining this information with the NLSS survey data on age and gender of each individual, a weighted average of per adult equivalent person (or consumption unit) nutrients requirements for a family is estimated as follows:

$$
\mathrm{RNA}_{\mathrm{cu}}=\sum_{\mathrm{a}=1}^{17} \sum_{\mathrm{g}=1}^{2} \mathrm{RNA}_{\mathrm{ag}}^{\mathrm{n}} * \mathrm{~S}_{\mathrm{ag}}^{\mathrm{p}}
$$

Where, RNA is recommended nutritional allowance, subscripts cu stands for consumption unit, $\mathrm{n}$ for nutrients (calories, fats and proteins) requirement, a for age groups divided into 17 groups (as provided in the DFTQC 2017), and $\mathrm{g}$ for gender of individual, $\mathrm{p}$ and $\mathrm{S}$ represents population and share of population in each age group and gender respectively. Using equation (2), daily per-capita requirements of calories, fats and proteins for a typical household is estimated.

Since NLSS collects food consumption information for a household and not of an individual, scale of CU as suggested in the NLSS itself is used to estimate per capita consumption expenditure. The method converts the individuals in a household into male adults (between 20 and 39 years old) equivalent using an "adult equivalent energy intake" (AEEI). Then, per consumption unit per day nutritional intakes of calories, fats and proteins, as presented in equation (3) is estimated.

$$
n_{p c u}=\frac{f * N}{C U_{h}}
$$

Where, $C U_{h}=\sum K_{-} c a l_{i} / K_{-} c a l_{m 20-39}$; ' $\mathrm{f}$ ' is portion (quantity) of food items consumed by a household, $\mathrm{N}$ is the nutrient content (calories, fats and proteins), $\mathrm{CU}_{\mathrm{h}}$ is total consumption unit in a household, $K$ cali is calorie requirement of individual ' $i$ ' and ' $m 20-39$ ' represents male in the age group of 20-39 years.

3 Although the balanced diet concept includes many other micronutrients such as iron, vitamins, calcium, zinc, folic acid etc., for the sake of simplicity our methods only considered three major nutrients - calories, proteins and fats. 
22 | The Economic Journal of Nepal (Issue No. 151)

\section{Estimating Minimum Cost of Food Basket with Balanced Diet}

The information on normative nutritional requirements (calories, fats and proteins), nutritional content of food items, behavioural current consumption pattern and unit prices of food items can be used to derive a minimum cost required for consuming recommended nutrition level by workers and their families.

The study estimated the minimum cost required for purchasing a food basket complying balanced diet approach/criteria by observing the consumption pattern of the households in the lowest fractile (20 equal groups on the basis of per person total consumption expenditure) subject to meeting the nutritional norms. Using the survey data, we identified the lowest fractile group that meets the nutritional norm of balanced diet whose average food expenditure is considered as the minimum food expenditure required for purchasing the consumption basket with the recommended nutritional norms.

\section{Estimating the Cost of Non-food Expenditure}

The second component of the total consumption expenditure of a household is non-food expenditure. In order to determine the minimum required levels of non-food expenditure, we used the broad framework and guidelines suggested by the ILC 1957 and the SC judgment 1992 on the types of non-food items which should be considered for estimating total nonfood expenditure needs. In addition, we also used the broad method of classifying the nonfood items into two categories: essential and other'. Accordingly, we classified all the non-food items as reported in NLSS-III into essential non-food items (NFEe) and other non-food items (NFEo). NFEe includes items such as clothing, fuel and light, house rent, education, medical expenses, footwear, and transport (or conveyance) while the NFEo includes all other non-food items of usual expenditure such as recreation, festivals/ceremonies and provision for marriage expenditure, purchase and maintenance/repair of consumer durables, and taxes paid. Following the methodology of the India Expert Committee Report (2014), the study used the average monthly expenditure of the median class $\left(50^{\text {th }}\right.$ percentile) of the consumption distribution as the representative non-food expenditure for essential non-food items. For the second group - other non-food items - the poverty level fractile may represent the reasonable average expenditure on other non-food items ${ }^{4}$. Accordingly, the need-based total non-food expenditure of workers families is obtained by adding the expenditure incurred in two categories together as follows:

$$
\mathrm{NFE}_{\mathrm{h}}=\mathrm{NFE}_{\mathrm{e}_{-} \mathrm{med}}+\mathrm{NFE}_{\mathrm{o}_{-} \text {pov }} \ldots \ldots \ldots \ldots \ldots \ldots \text { (6) }
$$

Where, med is median class and pov is the poverty line of a fractile group.

\section{Estimation of Minimum Wage}

Once the minimum needs of workers and their families are estimated, minimum wage rate can be fixed in a way that all the minimum needs of workers and their families must be covered by minimum wage. This essentially implies that wage workers must be given a

4 The Rangarajan Expert Committee (2014) considered the sixth fractile for other non-food items, mainly because the poverty-level calories, proteins and fats intake norms were met by households in the sixth fractile group. 
wage at least to cover the minimum consumption needs of his/her families that can maintain both the work efficiency and the reasonable standard of living. While we adjust the standard minimum wage per worker for average number of wage workers in the family, it is also important to consider unemployment rate among the workers. This requires that the worker's earning should be adequate to meet the total consumption expenditure within the available days of employment to wage workers. The minimum wage rate for wage worker, hence, can be computed as follows:

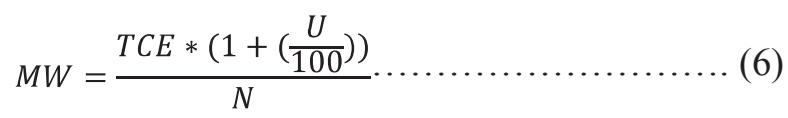

Where, MW is minimum wage rate; TCE is total household consumption expenditure need of workers, $\mathrm{N}$ is average number of wage workers per family and $\mathrm{U}$ is unemployment rate among wage workers.

Finally, we also allow for a day off in a week with full wage payment. If the minimum wage rate is fixed at daily rate, equation (5) must be adjusted (multiplied) with a ratio of (30/26), for covering household expenditure for 30 days with 26 days of wages.

\section{Results}

Table 1 presents results of the estimated average household size and consumption units along with average number of wage earners per household across different types of households classified on the basis of main source of livelihood.

Table 1: Household Size, Consumption Units, and No. of Workers by Types of Households

\begin{tabular}{|l|c|c|c|c|c|c|}
\hline \multirow{2}{*}{ Types of households } & \multicolumn{3}{c|}{ Average Household } & \multicolumn{3}{c|}{ Consumption Unit } \\
\cline { 2 - 8 } & Rural & Urban & Nepal & Rural & Urban & Nepal \\
\hline Wage employment in agriculture & 5.00 & 5.50 & 5.25 & 4.05 & 4.22 & 4.13 \\
\hline Wage employment in non-agriculture & 5.08 & 5.67 & 5.38 & 4.21 & 4.49 & 4.35 \\
\hline Self-employment in agriculture & 5.35 & 5.89 & 5.62 & 4.35 & 4.59 & 4.47 \\
\hline Self-employment in non-agriculture & 5.36 & 5.59 & 5.47 & 4.38 & 4.46 & 4.42 \\
\hline All households & 5.25 & 5.77 & 5.51 & 4.30 & 4.51 & 4.41 \\
\hline
\end{tabular}

Source: Author's Calculation using NLSS - III.

\section{Estimation of Minimum Food Expenditure}

Table 2 presents the estimated food expenditure for households meeting the nutrient norms in each fractile group. Since we can see that the 10th fractile group on an average meets the required nutrient norms, we consider the food expenditure by this group as representative consumption pattern with the minimum expenditure. The expenditure on food by the 10th fractile is NRs. 1763.19. 
24 | The Economic Journal of Nepal (Issue No. 151)

Table 2: Consumption Unit per Day and Monthly Food Expenditure by Fractile Groups

\begin{tabular}{|c|c|c|c|c|}
\hline $\begin{array}{c}\text { Fractile } \\
\text { Groups }\end{array}$ & Energy KCAL & Protein Gram & Fat Gram & $\begin{array}{c}\text { PC Food } \\
\text { Expenditure (NRs.) }\end{array}$ \\
\hline 1 & $1,332.48$ & 40.01 & 37.38 & $1,148.37$ \\
\hline 2 & $1,510.76$ & 43.25 & 30.67 & $1,183.01$ \\
\hline 3 & $1,977.71$ & 51.85 & 67.99 & $1,348.08$ \\
\hline 4 & $1,511.78$ & 43.15 & 38.65 & $1,443.06$ \\
\hline 5 & $1,671.03$ & 50.86 & 31.00 & $1,477.36$ \\
\hline 6 & $1,878.41$ & 51.12 & 46.91 & $1,553.87$ \\
\hline 7 & $1,887.04$ & 57.00 & 40.70 & $1,560.84$ \\
\hline 8 & $1,931.65$ & 55.55 & 40.43 & $1,643.09$ \\
\hline 9 & $2,221.95$ & 59.81 & 60.48 & $1,718.16$ \\
\hline 10 & $2,417.74$ & 93.34 & 46.34 & $1,763.19$ \\
\hline 11 & $2,286.73$ & 64.97 & 49.55 & $1,853.83$ \\
\hline 12 & $2,061.08$ & 60.48 & 45.77 & $1,961.83$ \\
\hline 13 & $1,988.57$ & 55.92 & 53.46 & $2,020.97$ \\
\hline 14 & $2,586.25$ & 74.79 & 52.92 & $2,056.87$ \\
\hline 15 & $2,127.67$ & 64.22 & 44.42 & $2,111.49$ \\
\hline 16 & $2,482.26$ & 75.58 & 50.86 & $2,281.20$ \\
\hline 17 & $2,535.44$ & 75.69 & 54.49 & $2,391.25$ \\
\hline 18 & $2,521.27$ & 76.95 & 55.28 & $2,524.74$ \\
\hline 19 & $2,595.56$ & 81.07 & 52.93 & $2,825.40$ \\
\hline 20 & $3,947.63$ & 120.28 & 74.77 & $3,488.50$ \\
\hline
\end{tabular}

Source: Author's Calculation using NLSS-III.

The food basket, along with per capita monthly consumption and expenditure of the $10^{\text {th }}$ fractile population is presented in Table 3. The food basket mainly reflects that households in the $10^{\text {th }}$ fractile spend $29.6 \%$ of their total food expenditure on cereals followed by $13.9 \%$ on fish and meat. Cooking oils and eggs and milk product constitute $11.2 \%$ and $8.77 \%$ of the total expenditure on food respectively. 
Raut: Setting National Minimum Wages for Nepal..... 25

Table 3: Consumption Unit of Different Food Items by Individual in the $10^{\text {th }}$ Fractile Group

\begin{tabular}{|l|c|c|c|}
\hline \multirow{2}{*}{\multicolumn{1}{|c|}{ Food items* }} & \multicolumn{3}{c|}{ Monthly Consumption } \\
\cline { 2 - 4 } & Quantity (Gram) & Value (Rs.) & $\begin{array}{c}\text { \% Distribution of } \\
\text { Value }\end{array}$ \\
\hline Grains and Cereals & 15,433 & 512.2 & 29.6 \\
\hline Pulses and Lentils & 1,557 & 114.1 & 6.6 \\
\hline Eggs and Milk Products & 2,487 & 150.4 & 8.7 \\
\hline Cooking Oils & 2,627 & 194.2 & 11.2 \\
\hline Vegetables & 3,804 & 81.2 & 4.7 \\
\hline Fruits and Nuts & 2,686 & 94.8 & 5.5 \\
\hline Fish and Meat & 1,144 & 239.4 & 13.9 \\
\hline Spices and Condiments & 396 & 47.3 & 2.7 \\
\hline Sweets and Confectionery & 874 & 39.3 & 2.3 \\
\hline Non-Alcoholic Beverages & - & 47.7 & 2.8 \\
\hline Alcoholic Beverages & - & 125.8 & 7.3 \\
\hline Tobacco \& Tobacco Products & - & 28.7 & 1.7 \\
\hline Misc. Food Products & - & 52.8 & 3.1 \\
\hline Total & $31,008.52$ & $1,727.94$ & 100.00 \\
\hline
\end{tabular}

Source: Author's Calculation using NLSS - III.

\section{Estimation of Minimum Non-food Expenditure}

Table 4 presents estimates of non-food expenditure classified into two categories, essential and other'. It can be seen that the $10^{\text {th }}$ fractile group requires NRs. 588.28 under essential category while $6^{\text {th }}$ fractile group requires NRs. 144.09 under other category.

Table 4: Per Consumption Unit Monthly Non-food Expenditure by Fractile Groups

\begin{tabular}{|c|c|c|c|c|c|}
\hline Fractile Groups & Essential & Other & Fractile Groups & Essential & Other \\
\hline 1 & 117.65 & 30.72 & 11 & 668.41 & 284.79 \\
\hline 2 & 181.30 & 61.81 & 12 & 752.20 & 331.39 \\
\hline 3 & 229.56 & 82.34 & 13 & 843.23 & 382.11 \\
\hline 4 & 273.31 & 102.42 & 14 & 959.65 & 460.28 \\
\hline 5 & 315.57 & 123.76 & 15 & $1,112.13$ & 557.25 \\
\hline 6 & 361.44 & 144.09 & 16 & $1,298.41$ & 683.26 \\
\hline 7 & 412.46 & 166.27 & 17 & $1,568.58$ & 861.88 \\
\hline 8 & 460.67 & 190.98 & 18 & $1,999.20$ & $1,161.72$ \\
\hline 9 & 520.05 & 217.48 & 19 & $2,851.42$ & $1,921.32$ \\
\hline 10 & 588.28 & 247.35 & 20 & $11,627.57$ & $5,576.77$ \\
\hline
\end{tabular}

Source: Author's Calculation using NLSS - III. 
Based on the estimation of minimum food and non-food expenditure, the monthly expenditure per consumption unit is NRs. 2495.56 and the total minimum monthly household expenditure on food and non-food consumption is NRs. 11000.40 at 2010/11 prices. In the next step, we will add to this the cost of housing to estimate the total minimum monthly expenditure as shown in Table 9 below.

\section{Cost of Housing}

Housing constitutes the second largest expenditure for the workers in developing countries (Anker \& Anker, 2017). The $11^{\text {th }}$ Sustainable Development Goals also prioritizes adequate, safe and sustainable housing as a pre-requisite to make cities and human settlements inclusive, safe, resilient and sustainable. A decent place to live removes the barriers to opportunity, success and health (Habitat for Humanity, 2019). Nepal living standard survey includes some indicators relating to the quality of the dwelling such as the number of rooms or size of dwelling, the materials of the walls, roof and floors, toilet facilities and access to water. In the context of fixation of minimum wages, it might be useful to distinguish households with and without a wage earner. Further, it might also be useful to take into account the place of residence in order to account for the cost of housing. For example, one has to live in urban areas due to job location paying higher housing rents while the job may not pay as much. Such households are, therefore, expected to be direct beneficiaries if the minimum wage policy was implemented. Table 5 shows the average and median monthly rent paid by the households with at least one wage earner separately for rural and urban areas; this is then compared to the households without wage earner.

Table 5: Average and Median Monthly Rent Paid by Households and Adult Equivalent by Rural and Urban Areas

\begin{tabular}{|c|l|c|c|c|c|c|}
\hline Area & $\begin{array}{c}\text { Types of } \\
\text { Households } \\
\text { Urban }\end{array}$ & $\begin{array}{c}\text { Average } \\
\text { Monthly } \\
\text { Rent }\end{array}$ & $\begin{array}{c}\text { Median } \\
\text { Monthly } \\
\text { Rent }\end{array}$ & $\begin{array}{c}\text { Average } \\
\text { Monthly } \\
\text { Rent per } \\
\text { Adult } \\
\text { Equivalent } \\
\text { without wage } \\
\text { earners }\end{array}$ & $\begin{array}{c}\text { Median } \\
\text { Monthly } \\
\text { Rent per } \\
\text { Adult } \\
\text { Equivalent }\end{array}$ & $\begin{array}{c}\text { No. of } \\
\text { Observations }\end{array}$ \\
\hline $\begin{array}{l}\text { Households } \\
\text { with at least } 1 \\
\text { wage earner }\end{array}$ & $3,059.91$ & $2,000.00$ & $1,082.89$ & 772.71 & 552 \\
\hline \multirow{2}{*}{ Rural } & $\begin{array}{l}\text { Households } \\
\text { without wage } \\
\text { earners }\end{array}$ & $1,643.33$ & $1,200.00$ & 948.81 & 625.00 & 15 \\
\cline { 2 - 7 } & $\begin{array}{l}\text { Households } \\
\text { with at least } 1 \\
\text { wage earner }\end{array}$ & $2,263.22$ & $1,150.00$ & 957.03 & 454.55 & 97 \\
\hline
\end{tabular}

Source: Author's Calculation using NLSS III. 


\section{Assessing the Level of Decency of a Dwelling}

To assess the quality of the house, we use a system of scoring based on the variables available including number of rooms, materials of the walls, roof and floors, the type of toilet facilities and the access to water. Our scoring system method is summarized in Annex 1 and 2. Then we calculate the monthly rent per adult equivalent corresponding to the housing scores. We can see in Table 6 that they are positively correlated indicating that the scores adequately captures the housing attributes. In other words, the higher the quality of house higher is its score and higher is the rent. Hence, we choose the monthly rent corresponding to the median score as the minimum cost of housing per consumption unit. In this case, NRs. 585.66 is the rental cost of housing corresponding to the median housing score of 13 .

Table 6: Total Housing Score and Monthly Rent per Adult Equivalent

\begin{tabular}{|c|c|c|c|}
\hline $\begin{array}{c}\text { Housing Total } \\
\text { Scores }\end{array}$ & $\begin{array}{c}\text { Monthly Rent per } \\
\text { Adult Equivalent }\end{array}$ & $\begin{array}{c}\text { Housing Total } \\
\text { Scores }\end{array}$ & $\begin{array}{c}\text { Monthly Rent per } \\
\text { Adult Equivalent }\end{array}$ \\
\hline 6 & - & 14 & 768.63 \\
\hline 7 & - & 15 & $1,064.50$ \\
\hline 8 & 65.82 & 16 & $1,403.13$ \\
\hline 9 & 295.68 & 17 & $1,465.54$ \\
\hline 10 & 300.43 & 18 & $1,823.84$ \\
\hline 11 & 402.49 & 19 & $3,041.93$ \\
\hline 12 & 442.48 & Total & $1,027.78$ \\
\hline 13 & 585.66 & & \\
\hline
\end{tabular}

Source: Author's Calculation using NLSS - III.

\section{Calculation of Minimum Wages}

Finally, based on estimates of minimum food, non-food and housing consumption, we calculate both monthly and daily minimum wages for a typical household. Table 7 shows that the total monthly per consumption unit expenditure is NRs. 3081.23. This number when multiplied by average consumption units in a household of $4.41^{5}$ yields total monthly household expenditure of NRs. 13,581.98. Finally, the inflation adjusted monthly household expenditure is NRs. 21799.98. Further, assuming that the effective working days for a worker are 26 in a month, we calculate daily wage rate at NRs. 838.43.

$5 \quad$ See Table 4. 
28 | The Economic Journal of Nepal (Issue No. 151)

Table 7: Estimation of the Daily National Minimum Wage in Nepalese Rupees

\begin{tabular}{|c|c|c|}
\hline \multicolumn{2}{|c|}{ Monthly per Consumption Unit (MPCU) Expenditure } & Value (in NPR.) \\
\hline \multicolumn{2}{|c|}{ Food expenditure (MPCU) } & $1,763.19$ \\
\hline \multirow{3}{*}{ Non-food expenditure (MPCU) } & Essential & 588.28 \\
\hline & Other & 144.09 \\
\hline & Rent & 585.66 \\
\hline \multicolumn{2}{|l|}{ Total expenditure (MPCU) } & 3081.23 \\
\hline \multicolumn{2}{|c|}{ Total monthly household expenditure (MPCU x 4.41 consumption units) } & $13,581.98$ \\
\hline \multicolumn{2}{|c|}{$\begin{array}{l}\text { Total monthly household expenditure Updated (Inflation adjusted } \\
2010 / 11 \text { to } 2019 / 20-(60.50 \% \text { CPI })\end{array}$} & 21799.07 \\
\hline \multicolumn{2}{|c|}{ Daily wage to cover 26 days (Monthly household expenditure /26) } & 838.43 \\
\hline
\end{tabular}

Source: Author's Calculation using NLSS - III.

\section{Discussion and Conclusions}

In Nepal, the minimum wage prescribed by the Government is mandatory and hence applicable to all workers/employees irrespective of status of the employment or the length of service. Table 8 shows the minimum wages effective from the date of publication of the Gazette Notice (DoP, 2016).

Table 8: Minimum Wage Prescribed by Government of Nepal 2016

\begin{tabular}{|c|l|c|c|}
\hline S.N. & Nature of Payments & $\begin{array}{l}\text { Minimum Monthly } \\
\text { Salary/wage (NRs.) }\end{array}$ & $\begin{array}{c}\text { Dearness Allowances } \\
\text { per month (NRs.) }\end{array}$ \\
\hline 1 & Monthly Salary & 6205 & 3495 \\
\hline 2 & Daily Wages & 395 & \\
\hline
\end{tabular}

Source: Gazette Notice (DoP, 2016)

New Labor Act - 2017 has replaced the Labor Act-1992 in 2017. The New Labor Act is passed for provisions for the rights, interest, facilities and safety of workers and employees working in enterprises of various sectors. The Ministry of Labor, Employment and Social Security has recently prescribed the minimum remuneration/wage of the worker/employees under Section 106 of the Labor Act -2017. Hence, Nepal has a government-mandated minimum wage, and no worker can be paid less then this mandatory minimum rate of pay. Employers in Nepal who fail to pay the Minimum Wage may be subject to punishment by Nepal's government.

A tripartite discussion between the government, employers and trade unions is held every two years to revise the minimum wage. Recently, as presented in Table 9, the Minimum Wages Fixation Committee revised upward the minimum monthly remuneration to Rs. 13,450 and a daily minimum wages to Rs. 517 , and an hourly wages to Rs. 69 . On the other hand, a differentiated minimum wage of Rs. 10,781.00 was established for the tea estate (Minimum Wage Tea Estate). The labour act does not differentiate workers between the informal and formal economy. 
Table 9: Minimum Wage as Noticed in Gazette - 2018

\begin{tabular}{|c|l|c|c|c|}
\hline \multicolumn{5}{|c|}{ A. Minimum Wage Other than Tea Estate } \\
\hline SN & $\begin{array}{c}\text { Minimum } \\
\text { Remuneration/Wage }\end{array}$ & $\begin{array}{c}\text { Basic Remuneration } \\
\text { (NRs.) }\end{array}$ & $\begin{array}{c}\text { Dearness Allowances } \\
\text { (NRs.) }\end{array}$ & $\begin{array}{c}\text { Total } \\
\text { (NRs.) }\end{array}$ \\
\hline 1 & Monthly & 8455 & 4995 & 13450 \\
\hline 2 & Daily & 325 & 192 & 517 \\
\hline 3 & Hourly & 43 & 26 & 69 \\
\hline \multicolumn{4}{|c|}{ B. Minimum Wages Tea Estate } \\
\hline SN & $\begin{array}{c}\text { Minimum } \\
\text { Remuneration/Wage }\end{array}$ & $\begin{array}{c}\text { Basic Remuneration } \\
\text { (NRs.) }\end{array}$ & $\begin{array}{c}\text { Dearness Allowances } \\
\text { (NRs.) }\end{array}$ & $\begin{array}{c}\text { Total } \\
\text { (NRs.) }\end{array}$ \\
\hline 1 & Monthly & 6469 & 4312 & 10781 \\
\hline 2 & Daily & 231 & 15 & 385 \\
\hline 3 & Hourly & 31 & 20 & 51 \\
\hline 4 & $\begin{array}{l}\text { Daily Allowances for the worker/employees working at Tea Processing } \\
\text { and Tea Factories and Sardar, Naike and Security Guard working in the } \\
\text { Tea Estate }\end{array}$ & 42 \\
\hline
\end{tabular}

Note: In addition to the Minimum Wage/Remuneration specified above benefits including Provident Fund and Gratuity provided under the Labor Act and Contribution Based Social Security Act 2017 (2074) and other prevailing laws should be provided.

Source: Gazette Notice (DoP, 2018)

Our estimates show that the ideal minimum wages at 2019/20 prices should be approximately NRs. 21800 , about 1.6 times the government's recommended wages. This is comparable to that of current minimum wages of India for July 2018 if rental allowance is not accounted for. Using similar approach, the expert committee in India estimated national minimum wages of Indian Rs. 9772.4; this is equivalent to NRs. 15634.84. Thus when we do not account for cost of housing, the national minimum wages is comparable between Nepal and India. This comparability of the minimum wages indicates that the cost of living in these two countries follow almost similar trend and structure. Likewise, this also suggests that the structures of these economies are somehow identical.

It may be also worthwhile to compare the estimated minimum wages of Nepal with the minimum wages that the Nepalese migrants receive in their destination countries. A study conducted by Centre for Technical Education and Vocational Training in 2015 shows that the minimum monthly wages that Nepalese migrants receive in these destinations is NRs. 18200 (CTEVT, 2014). This wage is comparable to our estimates when the migrants minimum wage at destination is adjusted for inflation. This has an important policy implication. Our estimates if considered by the policy makers in fixing minimum wages for Nepal, this will have important effects on work-related international out-migration from Nepal.

This study, therefore, follows ILO's recommendation of setting of minimum wages that is evidence based and takes into account both the needs of workers, their families and 
30 | The Economic Journal of Nepal (Issue No. 151)

economic condition. This study therefore calls for revising the minimum wages based on the comprehensive household survey of household dietary patterns and the expenditure made on consumption of food, non-food and housing items. It is recommended to re-estimate the minimum wages using the next Nepal Living Standard Survey (fourth round). This has at least two important advantages. One, we can check the robustness of the method applied to the data from NLSS-III. Second, we can account for the changes in the lifestyle over time and make appropriate adjustments to the criteria in estimation of minimum wages. Likewise, it may also be worthwhile to conduct further study by accounting for heterogeneity across various sub-national units (say by provinces). Also it may be useful to separately estimate minimum wages by skills and occupation.

To conclude, this study uses minimum needs approach to estimate minimum wages for Nepal by exploiting nationally representative household survey. In addition to the food and non-food consumption, this study also considers cost of housing while computing the minimum wages. The estimates show the minimum monthly wages of NRs. 21799 at 2019/20 prices and daily wage rate of NRs. 838.43 .

\section{Acknowledgement}

The author would like to thank Prof. Dr. Shiva Raj Adhikari for the conceptualization of the manuscript, and his constructive comments and feedback.

\section{References}

Addison, J. T. \& Blackburn, M. (1999). Minimum wages and poverty. Industrial and Labor Relations Review, 52(3), 393-409.

Anker, R. \& Anker, M. (2017). Living wages arround the world. Manual for Mersurement, Edward Elgar Publishing, Cheltenham.

Blinder, A. S. (2008). Keynesian economics. The concise encyclopedia of economics, 2(008).

CBS (Center Bureau of Statistics) (2011). Nepal Living Standard Survey - 2010/11, vol 1 \& 2, Government Nepal, Kathmandu

CTEVT (Centre for Technical Education and Vocational Training) (2014). Dynamics and Dimensions of Labour Migration from Nepal. Bhaktapur, Nepal.

Dickens, R. (2015). How are minimum wages set? IZA World of Labor. https://wol.iza.org/ uploads/articles/211/pdfs/how-are-minimum-wages-set.pdf

DFTQC (Department of Food Technology and Quality Control) (2017). Nepalese Food Composition Table-2017, National Nutrition Programme. Ministry of Agriculture Development, Government of Nepal.

DoP (Department of Printing) (2016). Gazette, Department of Printing, Ministry of Information and Communication, Government of Nepal, Kathmandu 
Estupinan, X. (2019). Application of minimum wages in Nepal: Challenges and opportunities. spotlight, 12019).

Freeman, R. B. (1996). The minimum wage as a redistributive tool. The Economic Journal, 106(436), 639-649.

GoI (Government of India) (2019). Report of the Expert Committee on Determining the Methodology for Fixing the National Minimum Wage Ministry of Labour and Employment, Government of India, New Delhi.

Habital for Humanity. (2020). About Advococy. Retrived from https://www.habitat.org/about/ advocacy/about.

Herr, H., \& Kazandziska, M. (2011). Principles of minimum wage policy-Economics, Institutions and Recommendations. Policy, (11), p.1-28.

ILO (International Labour Organization) (2014). Minimum Wage Systems: General Survey of the Reports on the Minimum Wage Fixing Convention, 1970 (No. 131), and the Minimum Wage Fixing Recommendation, 1970 (No.135), International Labour Conference, $103^{\text {rd }}$ Session (Geneva).

ILO (International Labour Organization) (2016). Minimum Wage Policy Guide. Inclusive Labour Markets, Labour Relations \& Working Conditions Branch (INWORK). Geneva: International Labour Organization.

ILO (International Labour Office) (2014). Minimum Wage System. International Labour Conference, $103^{\text {rd }}$ Session, 2014. International Labour Office. Geneva

MoLE/GoI. (2019). Report of the Expert Committee Determining the Methodology for Fixing the National Minimum Wages. Ministry of Labour and Employment. Government of India.

NLC (Nepal Law Commission) (1992). Labour Act, 2048 B. S. (1992 A. D.), Nepal Law Commission, Government of Nepal, Kathmandu

NLC (Nepal Law Commission) (2018). The Right to Employment Act, 2075B. S. (2018 A. D.). Nepal Law Commission, Government of Nepal, Kathmandu

Stigler, G. J. (1946). The economics of minimum wage legislation. The American Economic Review, 36(3), 358-365. 
32 | The Economic Journal of Nepal (Issue No. 151)

\section{Annex}

Figure 1: Scoring System Method to Assess Housing Quality.

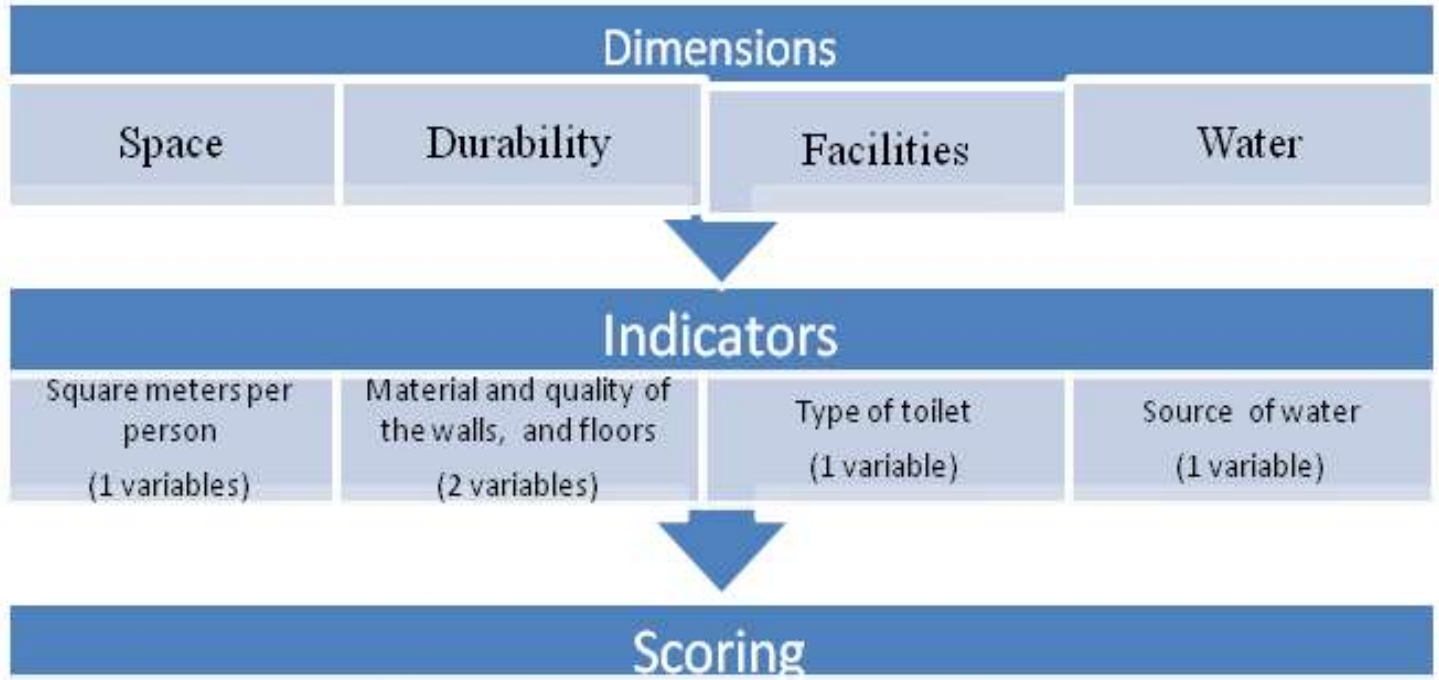

For each variables selected, create 5 categories going from:

1 (lowest quality) to 5 (highest quality) but in practice, maximum 4 scores are found

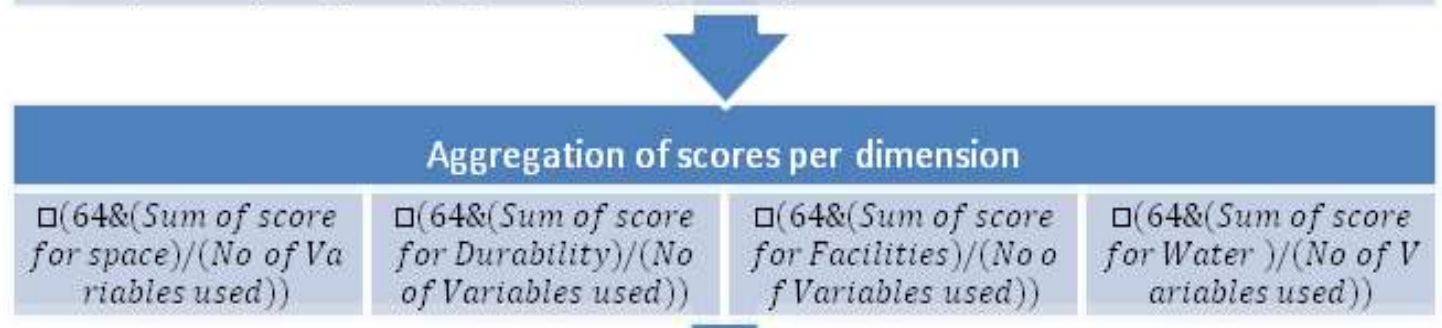

Round the scores to obtain one score per dimension going from 1 to 5

Sum up the scores of each of the dimensions

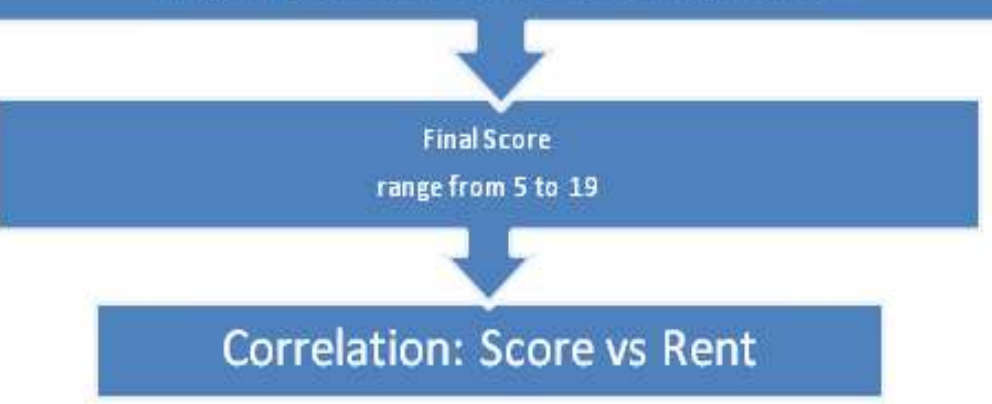


Table 8: Scoring System by Dimensions of Houses

\begin{tabular}{|c|c|c|c|c|c|}
\hline & \multicolumn{5}{|c|}{ Scores based on NLSS } \\
\hline & 1 & 2 & 3 & 4 & Remarks \\
\hline $\begin{array}{l}\text { Dwellings (Squared } \\
\text { meter per capita) }\end{array}$ & $<6$ sqm & 6-10 sqm & $10-20 \mathrm{sqm}$ & $\begin{array}{c}\text { More than } \\
20 \mathrm{sqm}\end{array}$ & \\
\hline Roof & $\begin{array}{l}\text { Straw/ } \\
\text { Thatch, } \\
\text { Earth/Mud }\end{array}$ & $\begin{array}{c}\text { Wood/ Planks, } \\
\text { Galvanized } \\
\text { Iron }\end{array}$ & Tiles/Slate & $\begin{array}{c}\text { Concrete/ } \\
\text { Cement }\end{array}$ & \\
\hline Walls & $\begin{array}{l}\text { Unbaked } \\
\text { Bricks, } \\
\text { Other } \\
\text { Material, } \\
\text { No Outside } \\
\text { Walls }\end{array}$ & $\begin{array}{c}\text { Wood, } \\
\text { Bamboo/ } \\
\text { Leaves }\end{array}$ & $\begin{array}{c}\text { Mud } \\
\text { Bonded } \\
\text { Bricks/ } \\
\text { Stones }\end{array}$ & $\begin{array}{l}\text { Cement } \\
\text { Bonded } \\
\text { Bricks/ } \\
\text { Stones }\end{array}$ & \\
\hline Water & $\begin{array}{l}\text { Open Well, } \\
\text { Spring } \\
\text { Water, River }\end{array}$ & $\begin{array}{c}\text { Covered Well, } \\
\text { Hand Pump/ } \\
\text { Tubewell }\end{array}$ & $\begin{array}{l}\text { Piped } \\
\text { Water } \\
\text { Supply }\end{array}$ & & $\begin{array}{c}\text { Piped } \\
\text { Water } \\
\text { Is Not } \\
\text { Directly } \\
\text { Drinkable. }\end{array}$ \\
\hline Toilet & $\begin{array}{l}\text { Communal } \\
\text { Latrine, No } \\
\text { Toilet }\end{array}$ & $\begin{array}{c}\text { Household } \\
\text { Flush } \\
\text { (Connected to } \\
\text { Septic Tank), } \\
\text { Household } \\
\text { Non-Flush }\end{array}$ & $\begin{array}{c}\text { Household } \\
\text { Flush } \\
\text { (Connected } \\
\text { to } \\
\text { Municipal } \\
\text { Sewer) }\end{array}$ & & \\
\hline
\end{tabular}

